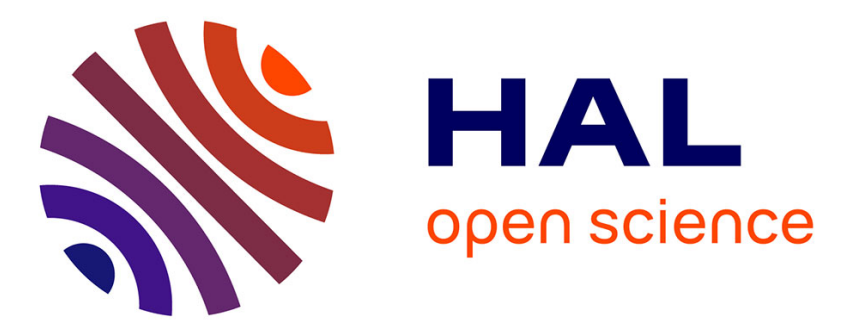

\title{
Impact of the support oxide and Ba loading on the sulfur resistance and regeneration of $\mathrm{Pt} / \mathrm{Ba} /$ Support catalysts
}

E.C. Corbos, Xavier Courtois, Nicolas Bion, Patrice Marecot, Daniel Duprez

\section{To cite this version:}

E.C. Corbos, Xavier Courtois, Nicolas Bion, Patrice Marecot, Daniel Duprez. Impact of the support oxide and Ba loading on the sulfur resistance and regeneration of $\mathrm{Pt} / \mathrm{Ba} / \mathrm{Support}$ catalysts. Applied Catalysis B: Environmental, 2007, 80 (1-2), pp.62-71. 10.1016/j.apcatb.2007.10.009 . hal-00300630

\section{HAL Id: hal-00300630 https://hal.science/hal-00300630}

Submitted on 26 Jan 2021

HAL is a multi-disciplinary open access archive for the deposit and dissemination of scientific research documents, whether they are published or not. The documents may come from teaching and research institutions in France or abroad, or from public or private research centers.
L'archive ouverte pluridisciplinaire HAL, est destinée au dépôt et à la diffusion de documents scientifiques de niveau recherche, publiés ou non, émanant des établissements d'enseignement et de recherche français ou étrangers, des laboratoires publics ou privés. 
Applied Catalysis B: Environmental 80 (2008) 62-71.

DOI: 10.1016/j.apcatb.2007.10.009

\title{
Impact of the support oxide and Ba loading on the sulfur resistance and regeneration of $\mathrm{Pt} / \mathrm{Ba} / \mathrm{Support}$ catalysts.
}

\author{
E.C. Corbos, X. Courtois, N. Bion, P. Marecot, D. Duprez \\ Laboratoire de Catalyse en Chimie Organique, UMR 6503 CNRS, Université de Poitiers, 40 \\ avenue du Recteur Pineau, 86022 Poitiers Cedex, France
}

\begin{abstract}
The influence of both the support oxide $\left(\mathrm{Al}_{2} \mathrm{O}_{3}, \mathrm{SiO}_{2}, \mathrm{Al}_{2} \mathrm{O}_{3}-5.5 \mathrm{wt} \% \mathrm{SiO}_{2}\right.$ and $\left.\mathrm{Ce}_{0.7} \mathrm{Zr}_{0.3} \mathrm{O}_{2}\right)$ and the barium loading of $\mathrm{Pt} / \mathrm{Ba} / \mathrm{Support}$ model catalysts on sulfur resistance was investigated by hydrogen temperature programmed reduction (TPR), X-ray diffraction (XRD) and NOx storage capacity measurements. The sulfation of catalysts under lean conditions in the presence of water and carbon dioxide led to the formation of both surface and bulk sulfates, except for silica supported catalyst on which mainly bulk barium sulfates were formed. Sulfate stability was influenced by the support oxide and the Ba loading. For alumina containing catalysts, both the amount of deposited sulfur and the sulfate stability under hydrogen increase with the $\mathrm{Ba}$ loading. Conversely the same sulfates stability was observed for $\mathrm{Ce}-\mathrm{Zr}$ supported samples, whatever the $\mathrm{Ba}$ loading. The thermal treatment of the sulfated catalysts under oxidizing conditions at $800^{\circ} \mathrm{C}$ favored the formation of less reducible bulk barium sulfates on all the catalysts. Ceria-zirconia led to a decrease of bulk $\mathrm{BaSO}_{4}$ stability under hydrogen, their reduction temperature being about $100^{\circ} \mathrm{C}$ lower than on alumina containing materials. The elimination of sulfates under rich conditions $\left(\mathrm{H}_{2}, \mathrm{CO}_{2}, \mathrm{H}_{2} \mathrm{O}, \mathrm{N}_{2}\right)$ was more effective on the ceria-zirconia supported sample compared to alumina containing catalysts, even after ageing at $800^{\circ} \mathrm{C}$.

Sulfation of the catalysts induced a loss of NOx storage capacity depending on catalyst composition. All the catalysts recovered their initial NOx storage capacity after regeneration at $550^{\circ} \mathrm{C}$, even with an improvement in the case of the ceria-zirconia supported material. The ageing at $800^{\circ} \mathrm{C}$ of sulfated catalysts before regeneration did not lower the performance of the $\mathrm{Pt} / 10 \mathrm{Ba} / \mathrm{CeZr}$ catalyst, contrary to the alumina containing samples.
\end{abstract}

Keywords: NOx storage, barium sulfate, ceria-zirconia, alumina, silica, sulfur elimination, regeneration. 


\section{Introduction}

In order to improve air quality, more and more stringent regulations are imposed to automotive manufacturers, especially for diesel and direct injection gasoline engines. These engines, operating under an excess of oxygen (lean conditions), have a potential to improve fuel efficiency and so to reduce $\mathrm{CO}_{2}$ emissions. However, excess of oxygen prevents conventional three-way catalysts from working effectively to reduce NOx. A promising solution to overcome this issue was introduced in the mid-1990s by Toyota with the concept of NOx storagereduction (NSR) [1]. This concept is based on the NOx storage by forming chemical compounds with a storage material under lean conditions followed by a short incursion in rich atmosphere (excess of hydrocarbons) where the stored NOx are released and reduced into $\mathrm{N}_{2}$.

Typically, NSR systems contain three major components: a basic storage material (alkaline or alkaline earth oxides, e.g. $\mathrm{BaO}$ ), a component for $\mathrm{NO}_{\mathrm{x}}$ oxidation/reduction (precious metals, e.g. Pt) deposited on a high surface support oxide (e.g. $\mathrm{Al}_{2} \mathrm{O}_{3}$ ) [2]. Nevertheless, the NSR systems are sensitive to sulfur (present in oils and gasoline) and temperature. It is known that, under lean conditions, $\mathrm{SO}_{2}$ coming from sulfur oxidation leads to the deactivation of NSR catalysts, due to the formation of stable sulfates which block storage sites [2-25]. The poisoning is reversible, and sulfates can be partly eliminated in rich conditions at high temperatures (600$750^{\circ} \mathrm{C}$ ) [8-12]. However, successive regenerations result in thermal deactivation of the catalyst [2]. The effect of sulfur was widely studied on $\mathrm{Pt} / \mathrm{Ba} / \mathrm{Al}$ catalysts [2-15]. The well dispersed barium sulfates located in Pt proximity are reducible at low temperatures whereas bulk-like species are reducible at relatively higher temperatures [5,9,10-12]. The regeneration of the storage component also depends on time [9] and on the nature of the reductant $[12,13]$. Hydrogen is more effective than carbon monoxide which is itself more effective than hydrocarbons $[12,13]$. Under rich conditions, sulfides are formed on the platinum particles, thus blocking the metal surface and hindering the further reduction function of the metal $[15,16]$. Moreover, under hydrogen, a part of sulfur is still present on the catalyst as barium sulfides, which are re-oxidized into sulfates under lean conditions leading to the poisoning of some storage sites. Nevertheless, it has been shown that sulfide formation is avoided when $\mathrm{CO}_{2}$ and $\mathrm{H}_{2} \mathrm{O}$ are present in the regeneration mixture [5,10].

Different strategies have been applied in order to improve sulfur resistance. One was to keep barium as storage material and to modify its properties by adding different compounds in order to decrease the desorption temperature of sulfates or prevent their formation: Fe [17], $\mathrm{Mg}$ [18], Li [4]. Matsumoto et al. [4] also investigated the role of the support oxide on sulfur resistance and showed that the stronger is the acidity of the support oxide the less is the amount of 
deposited sulfur. They concluded that an optimum of the acidity needs to be found in order to improve sulfur resistance and proposed an alumina-titania containing catalyst, with improved sulfur resistance. The mixing of a Pt/Ba/ $/ \mathrm{Al}_{2} \mathrm{O}_{3}$ catalyst with $\mathrm{Mn} / \mathrm{Ba} / \mathrm{Al}_{2} \mathrm{O}_{3}$ led to the formation of stable Mn sulfates over the latter and prevented the $\mathrm{Pt} / \mathrm{Ba} / \mathrm{Al}_{2} \mathrm{O}_{3}$ catalyst from significant poisoning, thus maintaining a high NOx storage in the presence of $\mathrm{SO}_{2}$ [19]. Hodjati et al. [20] showed that $\mathrm{BaSnO}_{3}$ perovskite type material presents a good NOx adsorption capacity in the presence of $\mathrm{SO}_{2}$ at low temperature $\left(200^{\circ} \mathrm{C}\right)$.

Other researchers attempted to enhance sulfur resistance of NSR catalysts by changing the storage material. Huang et al [21] improved sulfur resistance of the catalyst by substituting barium oxide for $\mathrm{TiO}_{2}$. They concluded that although the barium containing material had a better NOx storage capacity in the absence of $\mathrm{SOx}$, a Pt-Rh- $\mathrm{Al}_{2} \mathrm{O}_{3}-\mathrm{TiO}_{2}$ catalyst was more suitable on account of its superior sulfur resistance. They explained these results by a lower decomposition temperature of sulfates on $\mathrm{TiO}_{2}$. Takahashi et al [22] studied potassium containing catalysts and pointed out that an acidic mixed oxide (70 wt $\% \mathrm{ZrO}_{2}-30$ wt $\% \mathrm{TiO}_{2}$ ) was the best support against sulfur poisoning. Yamamoto et al. [23] used a $\mathrm{Pt} / \mathrm{LiO}_{2} / \mathrm{TiO}_{2}$ catalyst as NSR sorbent with high sulfur resistance. Centi et al. [24] proposed a PtCu catalyst deposited on a $\mathrm{Mg}$-Al support oxide obtained from a hydrotalcite type precursor and Clacens et al. [25] developed a non noble thioresistant $\mathrm{NOx}$ trap by blending $\mathrm{Cu} / \mathrm{ZrO}_{2}$ with a potassium/alumina material as active NOx storage catalysts with improved sulfur resistance, $\mathrm{Cu}$ being not able to oxidize $\mathrm{SO}_{2}$ into $\mathrm{SO}_{3}$.

We have reported recently [26] that the support oxide $\left(\mathrm{Al}_{2} \mathrm{O}_{3}, \mathrm{SiO}_{2}, \mathrm{Al}_{2} \mathrm{O}_{3}-5.5 \mathrm{SiO}_{2}\right.$ and $\mathrm{Ce}_{0.7} \mathrm{Zr}_{0.3} \mathrm{O}_{2}$ ) and $\mathrm{Ba}$ loading influence both the catalyst basicity and $\mathrm{Pt}-\mathrm{Ba}$ proximity, and thus catalyst performances in the presence of water and $\mathrm{CO}_{2}$. In this paper we further focus our attention on the critical question of catalyst deactivation by $\mathrm{SO}_{2}$ for previously studied samples. The effect of the thermal ageing under oxidizing conditions of sulfated catalysts was also investigated together with the regeneration of sulfated catalysts under hydrogen in the presence of $\mathrm{CO}_{2}$ and $\mathrm{H}_{2} \mathrm{O}$. These effects were investigated on the rapid NOx storage of catalysts under realistic conditions, i.e. in the presence of $\mathrm{CO}_{2}$ and $\mathrm{H}_{2} \mathrm{O}$ at $300^{\circ} \mathrm{C}$.

\section{Experimental}

Catalyst preparation, sulfation and regeneration

Four oxides were studied: $(\gamma)-\mathrm{Al}_{2} \mathrm{O}_{3}(\mathrm{Al}), \mathrm{SiO}_{2}(\mathrm{Si}), \mathrm{Al}_{2} \mathrm{O}_{3}-5.5 \% \mathrm{SiO}_{2}(\mathrm{Al} 5.5 \mathrm{Si})$ and $\mathrm{Ce}_{0.7} \mathrm{Zr}_{0.3} \mathrm{O}_{2}(\mathrm{CeZr}$ ) as barium support for $\mathrm{NOx}$ traps. The $\mathrm{Pt} / \mathrm{xBa} /$ Support (where $\mathrm{x}$ is the loading in wt $\%$ of $\mathrm{BaO}$ and Support represents the support oxide) catalysts were prepared using 
the following method. The support was first calcined at $500^{\circ} \mathrm{C}$ for $4 \mathrm{~h}$ under air and then impregnated with a barium nitrate solution, in order to obtain a 5, 10, 15, 20 or 30 wt $\% \mathrm{BaO}$ content. After drying at $120^{\circ} \mathrm{C}$ for 12 hours, the barium containing support was calcined at $700^{\circ} \mathrm{C}$ (heating rate $5^{\circ} \mathrm{C} / \mathrm{min}$ ) under air for $4 \mathrm{~h}$. The resulting powder was then impregnated with a dinitro-diamino platinum solution in order to obtain a $1 \mathrm{wt} \%$ Pt catalyst. After drying, the catalyst was calcined at $450^{\circ} \mathrm{C}$ under air for $2 \mathrm{~h}$ and then activated at $700^{\circ} \mathrm{C}$ for $4 \mathrm{~h}$ under a mixture containing $10 \% \mathrm{O}_{2}, 10 \% \mathrm{H}_{2} \mathrm{O}$, and $\mathrm{N}_{2}$. Pt/Support catalysts were prepared following the same protocol by adding platinum to the unmodified support.

In the sulfation process, the catalyst sample was exposed to a $100 \mathrm{ppm} \mathrm{SO}_{2}, 10 \% \mathrm{CO}_{2}, 10 \%$ $\mathrm{O}_{2}, 10 \% \mathrm{H}_{2} \mathrm{O}$ and $\mathrm{N}_{2}$ mixture at $300^{\circ} \mathrm{C}$ for $5 \mathrm{~h}$. After flushing at $300^{\circ} \mathrm{C}$ under $10 \% \mathrm{CO}_{2}, 10 \%$ $\mathrm{O}_{2}, 10 \% \mathrm{H}_{2} \mathrm{O}$ and $\mathrm{N}_{2}$ mixture for $15 \mathrm{~min}$, the catalyst was cooled down to room temperature under the same mixture. Water was removed from the flow at $100^{\circ} \mathrm{C}$. The amount of $\mathrm{SO}_{2}$ introduced during the sulfation treatment corresponds to a $2.0 \mathrm{wt} \% \mathrm{~S}$ content if all the sulfur is stored on the catalyst. The sulfated catalysts are denoted $\mathrm{Pt} / \mathrm{xBa} / \mathrm{Support}+\mathrm{S}$. Also, the effect of a thermal treatment under oxidizing conditions was studied. Samples of the sulfated catalysts were aged at $600^{\circ} \mathrm{C}$ and $800^{\circ} \mathrm{C}$ for 30 min under a mixture containing: $10 \% \mathrm{O}_{2}, 10 \% \mathrm{CO}_{2}, 10$ $\% \mathrm{H}_{2} \mathrm{O}$ and $\mathrm{N}_{2}$. The catalysts are then denoted $\mathrm{Pt} / \mathrm{xBa} /$ Support $+\mathrm{S}$ Ty (y: temperature of the final thermal treatment).

The regeneration of the sulfated catalysts was done with a rich mixture containing $2.5 \% \mathrm{H}_{2}, 10$ $\% \mathrm{CO}_{2}, 10 \% \mathrm{H}_{2} \mathrm{O}$ and $\mathrm{N}_{2}$. The catalysts were heated under this mixture from room temperature (except for $\mathrm{H}_{2} \mathrm{O}, 100^{\circ} \mathrm{C}$ ) up to the regeneration temperature $\left(500^{\circ} \mathrm{C}\right.$ or $550^{\circ} \mathrm{C}$, heating rate: $10^{\circ} \mathrm{C} \cdot \mathrm{min}^{-1}$ ) and maintained at this temperature for $30 \mathrm{~min}$ before cooling under $\mathrm{N}_{2}$.

\section{NOx storage capacity measurements}

The NOx storage capacities of the catalysts were measured at $300^{\circ} \mathrm{C}$. Before the NOx storage capacity measurements, the catalyst sample (60 $\mathrm{mg}$, particles diameter 0,1-0,25 mm) was pretreated at $300^{\circ} \mathrm{C}$ for 30 min under a $10 \% \mathrm{O}_{2}, 10 \% \mathrm{H}_{2} \mathrm{O}, 10 \% \mathrm{CO}_{2}$ and $\mathrm{N}_{2}$ mixture (total flow rate: $10 \mathrm{~L}^{-\mathrm{h}^{-1}}$ ). The sample was then submitted to a $350 \mathrm{ppm} \mathrm{NO}, 10 \% \mathrm{O}_{2}, 10 \% \mathrm{H}_{2} \mathrm{O}, 10$ $\% \mathrm{CO}_{2}$ and $\mathrm{N}_{2}$ mixture (total flow rate: $10 \mathrm{~L} \cdot \mathrm{h}^{-1}$ ). The gas flow was introduced using mass-flow controllers, except for $\mathrm{H}_{2} \mathrm{O}$ vapors which were introduced using a saturator thermostated at $46^{\circ} \mathrm{C}$. Both $\mathrm{NO}$ and $\mathrm{NOx}$ concentrations $\left(\mathrm{NO}+\mathrm{NO}_{2}\right)$ were followed by chemiluminescence with a COSMA Topaze 2020 apparatus. $\mathrm{H}_{2} \mathrm{O}$ was removed prior to NOx analysis with a membrane dryer. The NOx storage capacity was calculated by the integration of the recorded profile for the first 100s and platinum oxidation activity was estimated at saturation (usually about 900s) as the $\mathrm{NO}_{2} / \mathrm{NOx}$ ratio (\%). Under the conditions used in $\mathrm{NOx}$ storage measurements $(60 \mathrm{mg}$, 


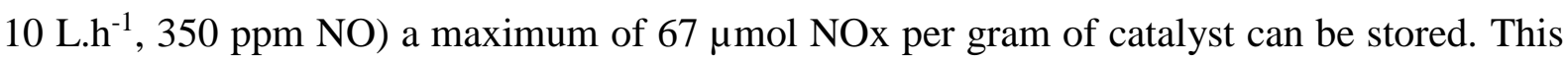
corresponds to the complete trapping of NOx injected on the catalyst in 100s.

\section{Catalyst characterizations}

The in-situ XRD measurements at different temperatures were carried out in an Anton PAAR HTK16 high-temperature stainless chamber linked to a Siemens D8 (Bragg-Brentano $\theta-\theta$ ) powder diffractometer. The powders were supported on a Kanthal foil. The powders were heated under air to the desired temperature with a heating rate of $10^{\circ} \mathrm{C} \cdot \mathrm{min}^{-1}$. Diffractogramms were recorded from $2 \theta=10^{\circ}$ to $70^{\circ}$, with an increment of $0.02^{\circ} 2 \theta$, dwell time $2 \mathrm{~s}$ at $25^{\circ} \mathrm{C}$ and after annealing the catalysts for $0.5 \mathrm{~h}$ at $600^{\circ} \mathrm{C}$ and $800^{\circ} \mathrm{C}$. The crystalline phases were identified by comparison with the ICDD database files

The BET surface areas were deduced from $\mathrm{N}_{2}$ adsorption at $-196^{\circ} \mathrm{C}$ carried out with a Tristar 3000 Micromeritics apparatus. Prior to the measurement, the samples were pretreated at $350^{\circ} \mathrm{C}$ under vacuum for $12 \mathrm{~h}$ in order to eliminate the adsorbed species. The BET surface areas of the support oxides were $144 \mathrm{~m}^{2} \cdot \mathrm{g}^{-1}, 147 \mathrm{~m}^{2} \cdot \mathrm{g}^{-1}, 317 \mathrm{~m}^{2} \cdot \mathrm{g}^{-1}$, and $80 \mathrm{~m}^{2} \cdot \mathrm{g}^{-1}$ for $\mathrm{Al}_{2} \mathrm{O}_{3}, \mathrm{SiO}_{2}, \mathrm{Al}_{2} \mathrm{O}_{3^{-}}$ 5.5 wt \% Si and $\mathrm{Ce}_{0.7} \mathrm{Zr}_{0.3} \mathrm{O}_{2}$, respectively. The BET surface areas of the catalysts are listed in Table 1.

Table 1: BET surface areas of the Pt/xBa/Support catalysts.

\begin{tabular}{lcc|cc|ccc|ccc}
\hline Support & \multicolumn{2}{c|}{ Al } & \multicolumn{2}{c|}{ Si } & \multicolumn{3}{c|}{ Al5.5Si } & \multicolumn{3}{c}{ CeZr } \\
\hline BaO (wt \%) & 10 & 20 & 10 & 20 & 10 & 20 & 30 & 5 & 10 & 20 \\
\hline BET $\left(\mathbf{m}^{\mathbf{2}} \mathbf{g}^{-1}\right)$ & 126 & 74 & 106 & 78 & 319 & 200 & 160 & 56 & 43 & 27 \\
\hline
\end{tabular}

\section{$\underline{\text { Temperature programmed reduction (TPR) }}$}

Prior to the TPR, the catalyst (65 mg) was first pretreated in situ under oxygen at $300^{\circ} \mathrm{C}$ for 30 $\mathrm{min}$ and cooled to room temperature. After flushing under argon for $45 \mathrm{~min}$, the reduction was carried out from room temperature up to $800^{\circ} \mathrm{C}$ under a $1 \% \mathrm{H}_{2} / \mathrm{Ar}$ mixture, using a $5^{\circ} \mathrm{C} \mathrm{min}{ }^{-1}$ heating rate. The sample was maintained at $800^{\circ} \mathrm{C}$ for $30 \mathrm{~min}$ before cooling under argon. Hydrogen consumption was followed by thermal conductivity.

\section{Results and discussion}

Influence of the support oxide on sulfate stability under hydrogen

It is well known that the presence of sulfur species in the exhaust gas leads to the formation of sulfates deactivating thus the NSR catalysts [2-15]. To further investigate the way the support oxide may influence sulfates formation and their stability, the different materials were sulfated under oxidizing conditions at $300^{\circ} \mathrm{C}$ in order to obtain a sulfur content of $2 \mathrm{wt} \%$ if all sulfur 
was deposited on the catalyst. To obtain information about the stability of sulfur species and the amount of deposited sulfur, the sulfated catalysts were characterized by TPR under hydrogen.

Figure 1 shows the TPR profiles of the different sulfated catalysts. The hydrogen consumptions and the corresponding amounts of deposited sulfur are listed in Table 2.
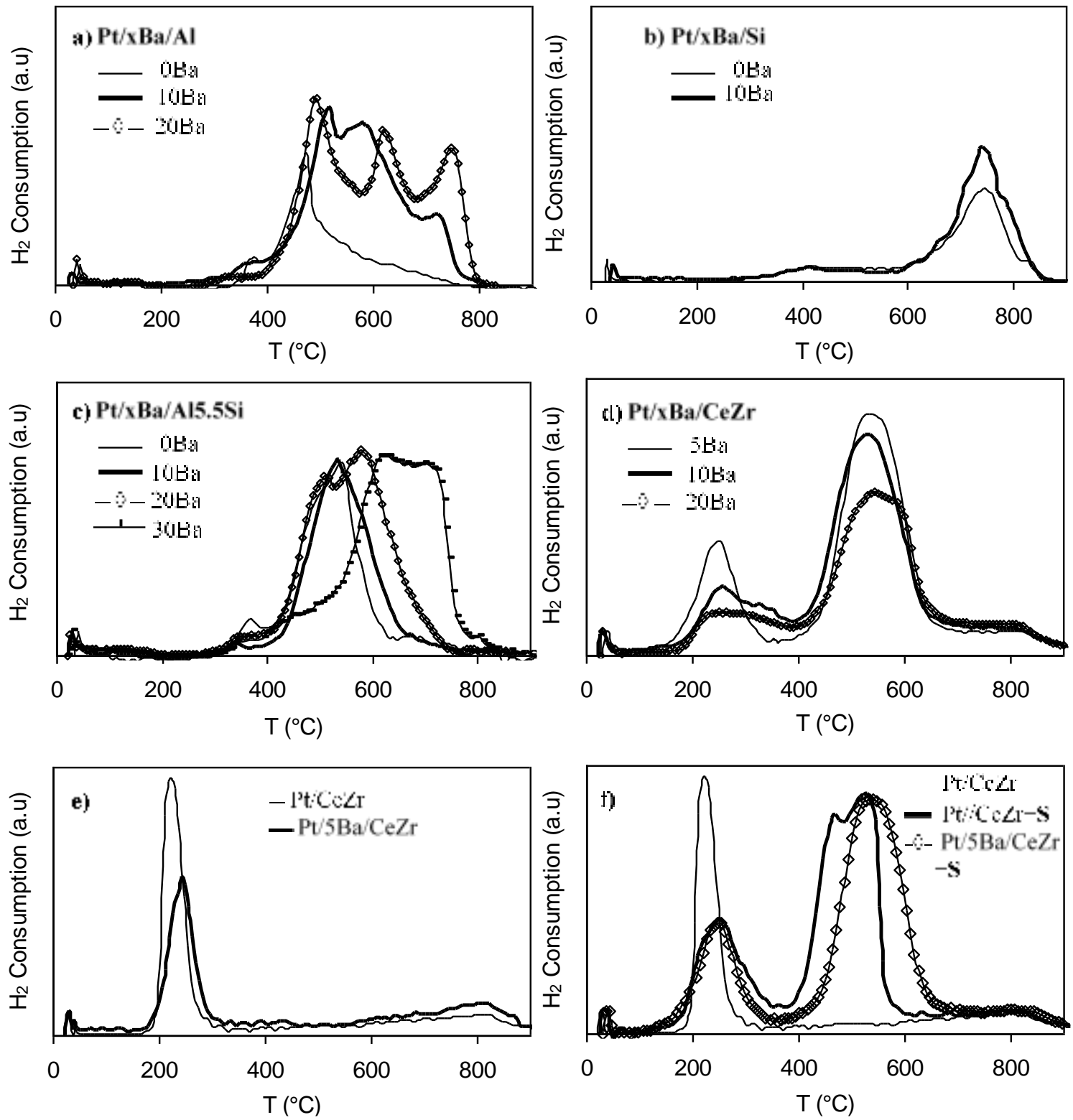

Figure 1: TPR profiles of sulfated catalysts. Sulfation was carried out at $300^{\circ} \mathrm{C}$ under oxidizing conditions. 
Table 2: $\mathrm{H}_{2}$ consumptions during TPR of sulfated catalysts and sulfur contents (wt \%).

\begin{tabular}{l|c|c|c|c|c|c|c|c|c|c|c|c|c|c}
\hline Support & \multicolumn{3}{|c|}{ Al } & \multicolumn{3}{c|}{ Si } & \multicolumn{5}{c|}{ Al5.5Si } & \multicolumn{5}{c}{ CeZr } \\
\hline BaO (wt\%) & 0 & 10 & 20 & 0 & 10 & 20 & 0 & 10 & 20 & 30 & 0 & 5 & 10 & 20 \\
\hline $\mathbf{H}_{\mathbf{2}}$ (mmol.g-1) & 0.87 & 1.95 & 2.40 & 0.05 & 0.86 & 1.06 & 1.41 & 1.53 & 2.27 & 2.45 & 1.58 & 1.72 & 1.61 & 1.14 \\
\hline S (wt\%) & 0.70 & 1.56 & 1.92 & $\sim 0$ & 0.67 & 0.85 & 1.13 & 1.22 & 1.82 & 1.96 & 1.26 & 1.38 & 1.29 & 0.91 \\
\hline
\end{tabular}

Fig. 1 and Table 2 show that both sulfate stability under hydrogen and the amount of deposited sulfur are influenced by the support oxide and the Ba loading. In order to determine the effect of sulfating at $300^{\circ} \mathrm{C}$ on the formation of aluminum sulfates, a $\mathrm{Pt} / \mathrm{Al}$ catalyst was sulfated at $300^{\circ} \mathrm{C}$ and then characterized by TPR. The reduction profile of the sulfated Pt/Al catalyst shows a hydrogen consumption between $350^{\circ} \mathrm{C}$ and $700^{\circ} \mathrm{C}$ (Fig. 1a). The peak near $450^{\circ} \mathrm{C}$ corresponds to the reduction of surface aluminum sulfates located in the platinum proximity while hydrogen consumption at higher temperatures can be attributed to the reduction of aluminum sulfates more and more distant from the metal function. The TPR profile of the sulfated $\mathrm{Pt} / 20 \mathrm{Ba} / \mathrm{Al}$ catalyst shows the presence of three main peaks (Fig. 1a). When comparing the TPR profile of the sulfated $\mathrm{Pt} / \mathrm{Al}$ catalyst with that of the $\mathrm{Pt} / 20 \mathrm{Ba} / \mathrm{Al}$ catalyst (Fig. 1a) it can be observed that the latter presents a peak near $450^{\circ} \mathrm{C}-500^{\circ} \mathrm{C}$ more intense than the $\mathrm{Pt} / \mathrm{Al}$ catalyst. These results indicate that in this temperature range the reduction of aluminum sulfates takes place simultaneously with the reduction of some well dispersed barium sulfates, located in platinum proximity. The two other peaks observed around $650^{\circ} \mathrm{C}$ and $750^{\circ} \mathrm{C}$ for the $\mathrm{Pt} / 20 \mathrm{Ba} / \mathrm{Al}$ catalyst are ascribed to the reduction of surface and bulk barium sulfates, respectively. It is known in the literature [5,11], that barium sulfates reduction depends on their size and location towards platinum particles, small surface sulfates located in the platinum proximity being easily reducible. On the other hand, the reduction of large barium sulfates (bulk like species > $10 \mathrm{~nm}$ ) is mostly relied on gas-solid phase reaction between sulfates and $\mathrm{H}_{2}$ [11]. The decrease of the Ba loading for the $\mathrm{Pt} / \mathrm{Ba} / \mathrm{Al}$ catalysts induces mainly a decrease of the $\mathrm{H}_{2}$ consumption for the reduction of bulk barium sulfates (Fig. 1a). Nevertheless, decreasing the Ba loading tends to shift the surface sulfate reduction temperatures. This result may be explained by previous characterizations of these samples [26], showing different Pt-Ba proximity linked to different $\mathrm{Pt}$ and $\mathrm{Ba}$ dispersions.

Assuming a $\mathrm{H}_{2} / \mathrm{SO}_{4}{ }^{2-}$ ratio of 4 for the sulfate reduction $\left(\mathrm{X}-\mathrm{SO}_{4}+4 \mathrm{H}_{2} \rightarrow \mathrm{X}-\mathrm{S}+4 \mathrm{H}_{2} \mathrm{O}\right.$ and/or $\mathrm{X}-\mathrm{SO}_{4}+4 \mathrm{H}_{2} \rightarrow \mathrm{X}-\mathrm{O}+\mathrm{H}_{2} \mathrm{~S}+3 \mathrm{H}_{2} \mathrm{O}$ ), a total sulfur content of $1.9 \mathrm{wt} \%$ on the $\mathrm{Pt} / 20 \mathrm{Ba} / \mathrm{Al}$ catalyst was deduced from hydrogen consumption (Table 2). This value is very close to the 
amount of sulfur injected in the gas flow during the sulfation treatment ( $2 \mathrm{wt} \%)$. The lower amounts of sulfur deposited on the Pt/10Ba/Al (1.6 wt \% S) and Pt/Al (0.7 wt \% S) catalysts confirm that the barium component is more active than alumina for sulfate formation.

No significant sulfur deposition was observed after the sulfation treatment of the $\mathrm{Pt} / \mathrm{SiO}_{2}$ catalyst (Fig. 1b) in agreement with previous works reported in the literature [27]. The addition of the $\mathrm{Ba}$ component to the material led to the formation of barium sulfates with a main reduction peak between $600^{\circ} \mathrm{C}$ and $800^{\circ} \mathrm{C}$, whatever the barium loading is, as indicated by the TPR profiles (Fig. $1 \mathrm{~b}$ ). This peak, with a maximum near $750^{\circ} \mathrm{C}$ was attributed to the reduction of bulk barium sulfates. The small hydrogen consumption observed between $350^{\circ} \mathrm{C}$ and $600^{\circ} \mathrm{C}$ may correspond to the reduction of very few surface barium sulfates. This result is in agreement with the very low NOx storage capacities measured on silica supported catalysts and reported in a previous work [26]. The low amounts of deposited sulfur, $0.7 \mathrm{wt} \%$ and 0.9 wt $\%$ for $\mathrm{Pt} / 10 \mathrm{Ba} / \mathrm{Si}$ and $\mathrm{Pt} / 20 \mathrm{Ba} / \mathrm{Si}$, respectively, are mainly explained by both the absence of sulfate deposition on the $\mathrm{SiO}_{2}$ support and the lower rate for bulk barium sulfation in comparison with surface species [15].

The alumina-silica supported catalysts present a similar behavior with alumina supported materials. Sulfate stability and the amount of sulfur increase with the Ba loading (Fig. 1c and Table 2). The TPR profile of the sulfated Pt/A15.5Si catalyst indicates that the reduction of aluminum sulfates takes place between $350^{\circ} \mathrm{C}$ and $700^{\circ} \mathrm{C}$, as previously observed for the sulfated $\mathrm{Pt} / \mathrm{Al}$ catalyst. However, the reduction peak is more intense than for the $\mathrm{Pt} / \mathrm{Al}$ sample. the higher surface area of the alumina-silica support compared with the alumina support (319 $\mathrm{m}^{2} \cdot \mathrm{g}^{-1}$ versus $144 \mathrm{~m}^{2} \cdot \mathrm{g}^{-1}$, respectively) allows one to explain this result since mainly surface sulfates are formed on alumina [3,6]. The $\mathrm{Pt} / 10 \mathrm{Ba} / \mathrm{Al}$.5Si catalyst shows only one reduction peak near $500^{\circ} \mathrm{C}$, slightly larger than that of the Pt/Al5.5Si catalyst $(1.2 \mathrm{wt} \% \mathrm{~S}$ versus $1.1 \mathrm{wt}$ $\% \mathrm{~S})$. This peak was attributed, as previously for alumina supported materials, to the reduction of both aluminum sulfates and well dispersed barium sulfates located in platinum proximity. Increasing the $\mathrm{Ba}$ loading to $20 \mathrm{wt} \% \mathrm{BaO}$ led to the appearance of a second peak near $600^{\circ} \mathrm{C}$ which can be attributed to the reduction of more crystallized surface barium sulfates. Finally, the increase of the $\mathrm{Ba}$ content to $30 \mathrm{wt} \% \mathrm{BaO}$ favored the formation of less reducible barium sulfates indicated by the drop of the hydrogen consumption between $400^{\circ} \mathrm{C}$ and $600^{\circ} \mathrm{C}$, and the apparition of a broad peak in the $600^{\circ} \mathrm{C}-800^{\circ} \mathrm{C}$ temperature range. This evolution is linked to the formation of bulk barium sulfates to the detriment of well dispersed surface barium sulfates. These results are in agreement with the XRD measurements on the Pt/Ba/A15.5Si materials, reported in a previous work [26], pointing out that the $\mathrm{BaCO}_{3}$ phase was detected only on the 
$\mathrm{Pt} / 30 \mathrm{Ba} / \mathrm{A} 15.5 \mathrm{Si}$ catalyst. Under a $\mathrm{SO}_{2}$ containing mixture bulk carbonates on this sample are progressively replaced by bulk barium sulfates.

The TPR profiles of the sulfated ceria-zirconia containing samples are depicted in Fig. 1d. For comparison, the reduction curve of the fresh $\mathrm{Pt} / \mathrm{CeZr}$ catalyst is also reported (Fig. 1e). This curve shows a main reduction peak near $220^{\circ} \mathrm{C}$ attributed to the reduction of $\mathrm{Ce}^{4+}$ to $\mathrm{Ce}^{3+}$ promoted by platinum [28,29]. The hydrogen consumption corresponds approximately to the reduction of three layers of cerium (the surface and two bulk layers). The small wave of hydrogen consumption at higher temperatures $\left(400-800^{\circ} \mathrm{C}\right)$ is related to the reduction of deeper bulk cerium atoms (Fig. 1e). Fig. 1e shows that the addition of $\mathrm{BaO}$ to ceria-zirconia support led to a slight shift of the main reduction peak of ceria to higher temperatures. Sulfation of the $\mathrm{Pt} / \mathrm{CeZr}$ catalyst led to both a broadening of the low temperature peak with a shift of the maximum to higher temperatures $\left(250^{\circ} \mathrm{C}\right.$ versus $\left.220^{\circ} \mathrm{C}\right)$ and the appearance of a large peak between $400^{\circ} \mathrm{C}$ and $600^{\circ} \mathrm{C}$ (Fig. 1f). The latter corresponds to the reduction of surface and bulk sulfates formed on ceria-zirconia support $[3,30]$. The addition of barium to ceria-zirconia induced a shift of the reduction of sulfates to higher temperature (Fig. 1f). Nevertheless, all the sulfates are reduced before $650^{\circ} \mathrm{C}$ regardless of the Ba loading (Fig. 1d). Surprisingly, the amount of deposited sulfur for ceria-zirconia catalysts decreases as the Ba loading increases (Table 2): 1.4 wt $\%$ for $\mathrm{Pt} / 5 \mathrm{Ba} / \mathrm{CeZr}, 1.3$ wt $\%$ for the $\mathrm{Pt} / 10 \mathrm{Ba} / \mathrm{CeZr}$ and 0.9 wt $\% \mathrm{~S}$ for the $\mathrm{Pt} / 20 \mathrm{Ba} / \mathrm{CeZr}$ catalyst, with no significant changes in sulfate stability. The decrease of the amount of sulfur might be due to both the lower BET surface area of the materials with higher Ba loadings (Table 1) and the limitation of $\mathrm{SO}_{\mathrm{x}}$ species diffusion in the bulk at $300^{\circ} \mathrm{C}$ due to higher barium particles (19 $\mathrm{nm}$ for $\mathrm{Pt} / 5 \mathrm{Ba} / \mathrm{CeZr}$ versus $51 \mathrm{~nm}$ for $\mathrm{Pt} / 10 \mathrm{Ba} / \mathrm{CeZr}$ [26]).

\section{NOx storage capacity of sulfated catalysts}

The NOx storage capacities of sulfated $\mathrm{Pt} / \mathrm{Ba} / \mathrm{Al}, \mathrm{Pt} / \mathrm{Ba} / \mathrm{Al}$.5Si and $\mathrm{Pt} / \mathrm{Ba} / \mathrm{CeZr}$ catalysts were measured at $300^{\circ} \mathrm{C}$, in order to appreciate the impact of sulfur on the NOx trapping properties. $\mathrm{Pt} / \mathrm{Ba} / \mathrm{Si}$ catalysts are not discussed in this part since their NOx storage capacities are already very low before sulfur poisoning [26]. In real engines water and $\mathrm{CO}_{2}$ are always presents, therefore the NOx storage measurements were carried out in a mixture containing $10 \% \mathrm{O}_{2}, 10$ $\% \mathrm{CO}_{2}, 10 \% \mathrm{H}_{2} \mathrm{O}, 350 \mathrm{ppm} \mathrm{NO}$ and $\mathrm{N}_{2}$. The results are reported in Fig. 2. For comparison the NOx storage capacities of the fresh (non-sulfated) catalysts are also reported.

As expected, sulfation leads to a significant decrease of the NOx storage capacity that ranges between $50-70 \%$, depending on catalyst composition. The Pt/20Ba/Al5.5Si catalyst shows the higher NOx storage capacity $\left(11.1 \mu \mathrm{mol} . \mathrm{g}^{-1}\right)$ after the sulfation treatment. This catalyst, together 
with the ceria-zirconia supported samples present the lower sensitivity to sulfur with near $50 \%$ of loss of their initial NOx storage capacities. On the contrary, the alumina supported samples present the higher sulfur sensitivity, with approximately $70 \%$ of loss of the NOx storage capacity after sulfation.

In previous work, it was reported that NOx trapping ability decreased with the increase of the amount of $\mathrm{SO}_{2}$ injected on the catalyst [31]. In our case, there is no direct correlation between the NOx storage capacity of the catalysts after sulfation and the amount of deposited sulfur (Fig. 2 and Table 2). The difference may come from the fact that in their study, Engstrom et al. [31] added the $\mathrm{SO}_{2}$ in the course of the $\mathrm{NOx}$ storage measurement whereas we carried out the sulfation treatment before the NOx storage.

Fig. 2 shows that the catalysts did not entirely lose their NOx storage capacity, even if all the sulfur injected during sulfation was not deposited that is to say some sulfur was not able to adsorb on the catalyst. This result may be partially explained by the fact that a part of less stable surface sulfites and/or sulfates desorbs during the flushing carried out for 15 min after sulfation at $300^{\circ} \mathrm{C}$ under the $\mathrm{H}_{2} \mathrm{O}, \mathrm{O}_{2}$ and $\mathrm{CO}_{2}$ mixture. Indeed, Abdulhamid et al. [6] showed by FTIR measurements that the presence of water under lean conditions would lead to a decrease in the formation of surface barium sulfates. A direct consequence is a more or less deep "regeneration" of some surface sites which are able to retain NOx. Moreover, the formation of sulfates on the catalyst may also lead to a decrease of the material basicity and thus modify the $\mathrm{NOx} / \mathrm{CO}_{2}$ adsorption competition in favor of $\mathrm{NOx}$ [26].

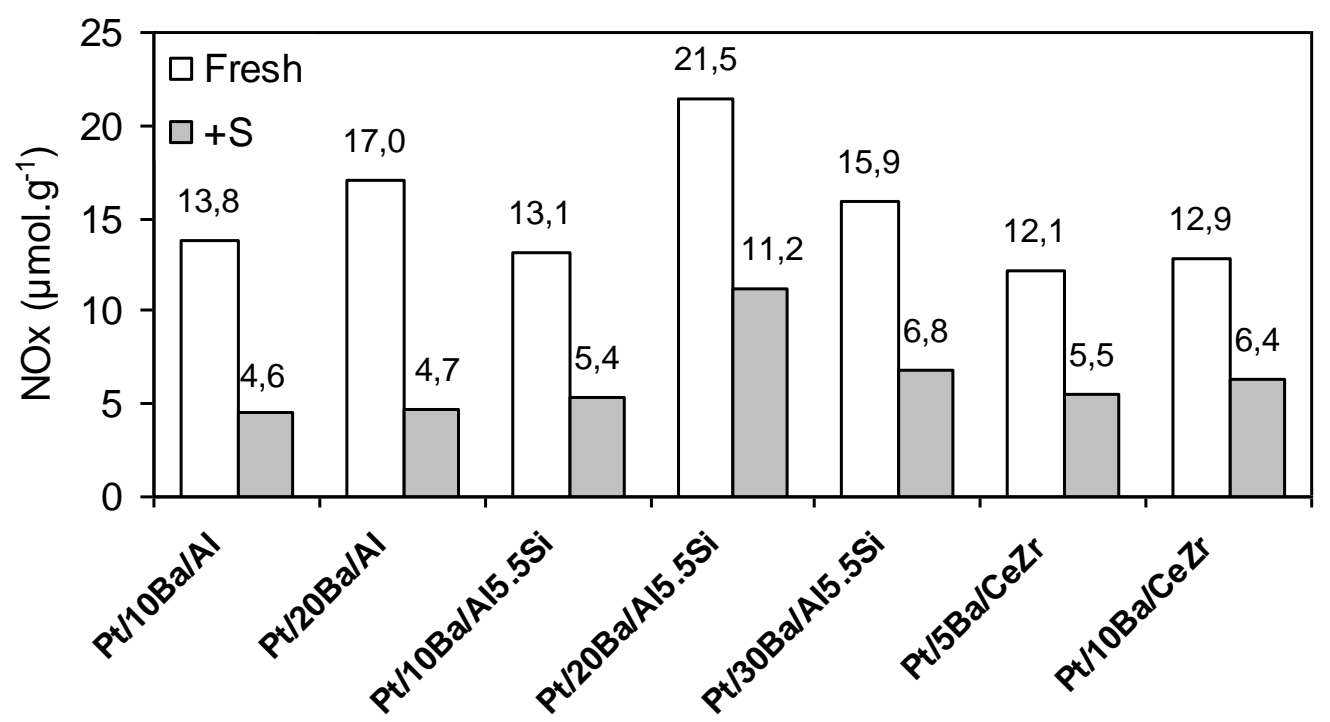

Figure 2: NOx storage capacities at $300^{\circ} \mathrm{C}$ of fresh and sulfated catalysts. 
$\underline{\text { Regeneration under } \mathrm{H}_{2}, \mathrm{CO}_{2} \text { and } \mathrm{H}_{2} \mathrm{O} \text { mixture }}$

The regeneration of sulfated catalysts was investigated at $500^{\circ} \mathrm{C}$ and $550^{\circ} \mathrm{C}$. In previous studies $[5,10]$, it was shown that the regeneration of a sulfated $\mathrm{Pt} / 20 \mathrm{Ba} / \mathrm{Al}$ catalyst under a mixture containing $\mathrm{H}_{2}, \mathrm{CO}_{2}$ and $\mathrm{H}_{2} \mathrm{O}$ at $650^{\circ} \mathrm{C}$ led to a total recovery of the NOx storage capacity, even if some sulfur species are still present on the catalyst. In order to determine the way the support may influence the regeneration efficiency, the sulfated $\mathrm{Pt} / 10 \mathrm{Ba} / \mathrm{Al}, \mathrm{Pt} / 20 \mathrm{Ba} / \mathrm{Al}$.5Si and $\mathrm{Pt} / 10 \mathrm{Ba} / \mathrm{CeZr}$ catalysts were characterized by TPR and NOx storage capacity measurements after a regeneration treatment at $500^{\circ} \mathrm{C}$ or $550^{\circ} \mathrm{C}$ for $0.5 \mathrm{~h}$ under a mixture containing $\mathrm{CO}_{2}, \mathrm{H}_{2} \mathrm{O}$, $\mathrm{H}_{2}$ and $\mathrm{N}_{2}$

Figure 3 depicts the TPR profiles of the regenerated catalysts. The TPR profiles of the sulfated catalysts are also reported for comparison. The amounts of remaining sulfur after the regeneration treatments are presented in Table 3. After regeneration at $550^{\circ} \mathrm{C}$, around $40 \%$ of the deposited sulfur are eliminated for the sulfated $\mathrm{Pt} / 20 \mathrm{Ba} / \mathrm{Al} 5.5 \mathrm{Si}$, around $50 \%$ for the sulfated $\mathrm{Pt} / 10 \mathrm{Ba} / \mathrm{Al}$ and more than $85 \%$ for the $\mathrm{Pt} / 10 \mathrm{Ba} / \mathrm{CeZr}$ (Table 3). Moreover, a stabilization of the remaining sulfates was observed in the case of the alumina and aluminasilica based materials as indicated by the shift of the reduction peak to higher temperatures (Figs. 3a and 3b). These results show that the regeneration treatment at $550^{\circ} \mathrm{C}$ led not only to sulfates elimination but also to a stabilization of some sulfur species previously formed at $300^{\circ} \mathrm{C}$ during the sulfation.

For the $\mathrm{Pt} / 10 \mathrm{Ba} / \mathrm{CeZr}$ catalyst, the regeneration treatment led to a shift of the reduction temperature of ceria oxide to lower temperature (Fig 3c). Ceria reduction promoted by platinum, starts from ambient temperature and finishes near $200^{\circ} \mathrm{C}$ for the regenerated sample while it presents a maximum near $250^{\circ} \mathrm{C}$ for the sulfated catalyst. This may be linked to the reduction of platinum particles and/or to a structural re-organization of ceria-zirconia [28] during the regeneration treatment under $\mathrm{H}_{2}, \mathrm{CO}_{2}$ and $\mathrm{H}_{2} \mathrm{O}$.

Interestingly, if the regeneration temperature is decreased from $550^{\circ} \mathrm{C}$ to $500^{\circ} \mathrm{C}$, the amount of eliminated sulfur (Table 3) does not decrease significantly for the $\mathrm{Pt} / 10 \mathrm{Ba} / \mathrm{Al}$ catalyst (about $0.7 \mathrm{wt} \% \mathrm{~S}$ is present after regeneration at $550^{\circ} \mathrm{C}$ and $0.8 \mathrm{wt} \% \mathrm{~S}$ for $500^{\circ} \mathrm{C}$ ). Furthermore, the regeneration at $500^{\circ} \mathrm{C}$ does not lead to sulfate stabilization as in the case of the catalyst regenerated at $550^{\circ} \mathrm{C}$, indicating that sulfate stabilization on such material get start at a temperature above $500^{\circ} \mathrm{C}$. The sulfated $\mathrm{Pt} / 20 \mathrm{Ba} / \mathrm{Al} 5.5 \mathrm{Si}$ catalyst does not present the same behavior than the $\mathrm{Pt} / 10 \mathrm{Ba} / \mathrm{Al}$ sample, since a stabilization of sulfated species was observed even after regeneration at $500^{\circ} \mathrm{C}$. Furthermore, the amount of eliminated sulfur increases with the regeneration temperature: near $30 \%$ and $40 \%$ of S were eliminated after regeneration at 
$500^{\circ} \mathrm{C}$ and $550^{\circ} \mathrm{C}$, respectively. The same behavior regarding sulfur elimination was observed for the $\mathrm{Pt} / 10 \mathrm{Ba} / \mathrm{CeZr}$ catalyst but the regeneration treatment takes place without any sulfate stabilization: $50 \%$ of deposited sulfur were eliminated after regeneration at $500^{\circ} \mathrm{C}$ compared to $\sim 90 \%$ after regeneration at $550^{\circ} \mathrm{C}$. These results show the interest for the introduction of ceria-zirconia oxides in the NSR formulations, on account of the lower barium sulfates stability under reducing atmosphere compared to alumina containing materials.
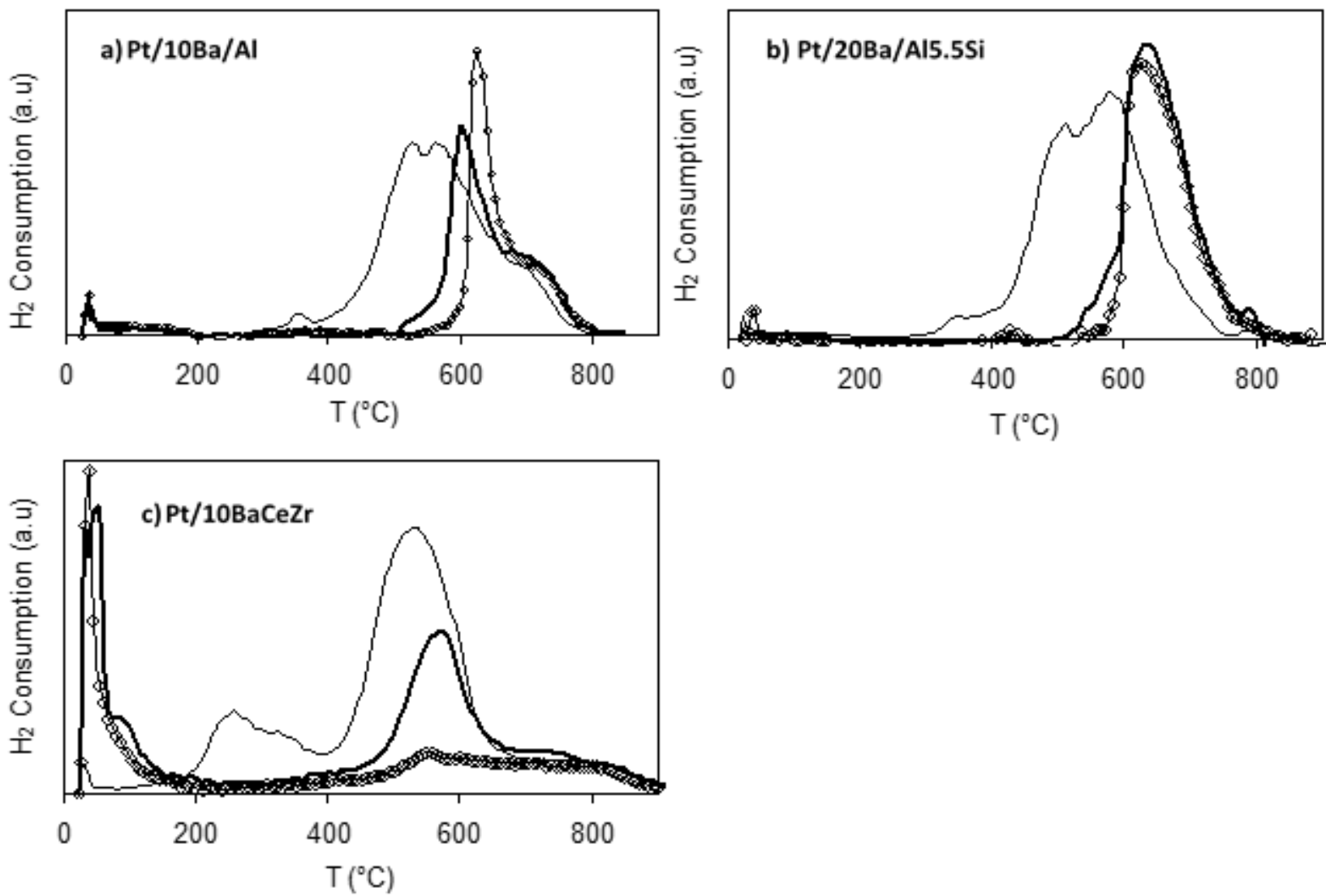

Figure 3: TPR profiles of (a) $\mathrm{Pt} / 10 \mathrm{Ba} / \mathrm{Al}$, (b) $\mathrm{Pt} / 20 \mathrm{Ba} / \mathrm{Al} 5.5 \mathrm{Si}$ and (c) $\mathrm{Pt} / 10 \mathrm{Ba} / \mathrm{CeZr}$. (-) sulfated; (-) sulfated and regenerated at $500^{\circ} \mathrm{C} ;(-\diamond-)$ sulfated and regenerated at $550^{\circ} \mathrm{C}$. The regeneration was carried out under $\mathrm{H}_{2}, \mathrm{CO}_{2}, \mathrm{H}_{2} \mathrm{O}$ and $\mathrm{N}_{2}$.

Table 3: $\mathrm{H}_{2}$ consumption and amount of sulfur for sulfated catalysts $(\mathrm{S})$, sulfated and aged at $600^{\circ} \mathrm{C}$ or $800^{\circ} \mathrm{C}$ catalysts (S T600 and S T800), sulfated and regenerated at $500^{\circ} \mathrm{C}$ and $550^{\circ} \mathrm{C}$ under $\mathrm{H}_{2}, \mathrm{CO}_{2}, \mathrm{H}_{2} \mathrm{O}$ (S R500, S R550) and sulfated, aged and regenerated at $550^{\circ} \mathrm{C}(\mathrm{S} \mathrm{T} 600$ R550 and S T800 R550).

\begin{tabular}{|c|c|c|c|c|c|c|c|c|}
\hline $\begin{array}{l}\text { Treatment } \\
\text { Catalyst }\end{array}$ & & $+\mathrm{S}$ & +S R500 & +S R550 & $+\mathrm{S}$ T600 & $+\mathrm{S}$ T800 & $\begin{array}{c}+\mathrm{S} \text { T600 } \\
\text { R550 }\end{array}$ & $\begin{array}{c}+S T 800 \\
R 550\end{array}$ \\
\hline \multirow{3}{*}{$\mathbf{H}_{2}\left(\mathrm{mmol} \mathrm{g}^{-1}\right)$} & Pt/10Ba/Al & 1.95 & 0.95 & 0.86 & 1.82 & 1.78 & 1.50 & 1.71 \\
\hline & Pt/20Ba/Al5.5Si & 2.27 & 1.52 & 1.34 & 2.20 & 2.24 & 1.38 & 1.95 \\
\hline & $\mathrm{Pt} / \mathbf{1 0 B a} / \mathrm{CeZr}$ & 1.61 & 0.81 & 0.20 & 1.60 & 1.45 & 0.58 & 0.70 \\
\hline \multirow{3}{*}{$\mathrm{S}(\mathrm{wt} \%)$} & Pt/10Ba/Al & 1.56 & 0.76 & 0.69 & 1.45 & 1.42 & 1.20 & 1.37 \\
\hline & Pt/20Ba/Al5.5Si & 1.82 & 1.22 & 1.07 & 1.76 & 1.79 & 1.10 & 1.56 \\
\hline & $\mathrm{Pt} / 10 \mathrm{Ba} / \mathrm{CeZr}$ & 1.29 & 0.64 & 0.16 & 1.28 & 1.16 & 0.46 & 0.56 \\
\hline
\end{tabular}




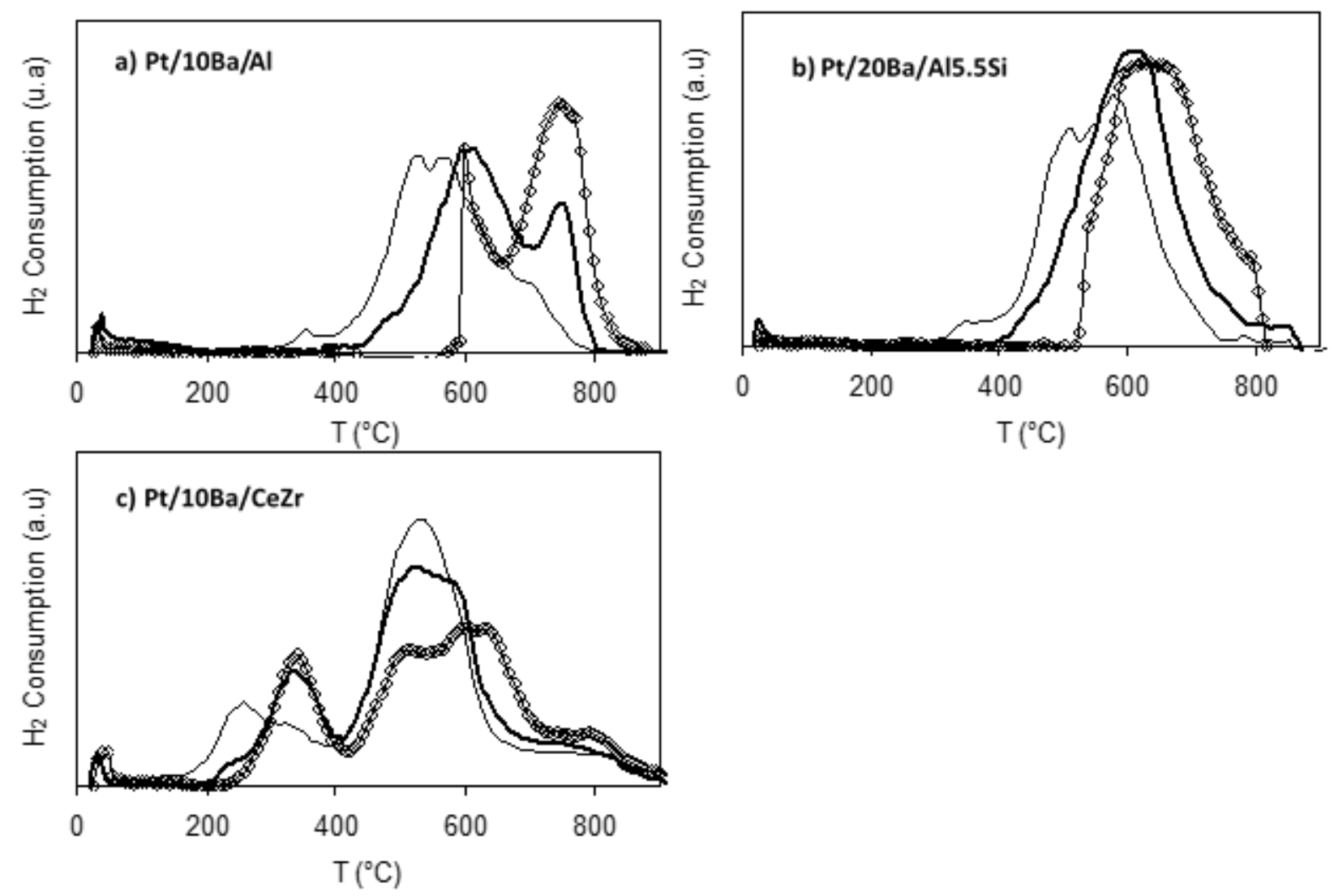

Figure 4: TPR profiles of a) $\mathrm{Pt} / 10 \mathrm{Ba} / \mathrm{Al}$, b) $\mathrm{Pt} / 20 \mathrm{Ba} / \mathrm{Al} 5.5 \mathrm{Si}$ and c) $\mathrm{Pt} / 10 \mathrm{Ba} / \mathrm{CeZr}$. (-) sulfated; (一) sulfated and aged at $600^{\circ} \mathrm{C} ;(-\diamond-) 800^{\circ} \mathrm{C}$ sulfated and aged at $800^{\circ} \mathrm{C}$. The ageing was carried out under $\mathrm{O}_{2}, \mathrm{H}_{2} \mathrm{O}, \mathrm{CO}_{2}$ and $\mathrm{N}_{2}$.

Thermal ageing of sulfated catalysts

As in real engines, the temperature of the exhaust gas may reach temperatures as high as 700$800^{\circ} \mathrm{C}$ or even more, we wanted to investigate the effect of thermal ageing of sulfated catalysts under oxidizing conditions on the efficiency of the subsequent regeneration treatment. Sulfated catalysts were aged at $600^{\circ} \mathrm{C}$ and $800^{\circ} \mathrm{C}$ under oxidizing conditions, and then regenerated at $550^{\circ} \mathrm{C}$. Figure 4 presents the TPR profiles of sulfated and aged catalysts. For comparison the TPR profiles of sulfated catalysts are also reported. The corresponding hydrogen consumptions and the quantities of stored sulfur are reported in Table 3.

For alumina containing catalysts $(\mathrm{Pt} / 10 \mathrm{Ba} / \mathrm{Al}$ and $\mathrm{Pt} / 20 \mathrm{Ba} / \mathrm{Al} 5.5 \mathrm{Si})$, the oxidizing treatment at $600^{\circ} \mathrm{C}$ led to the elimination of aluminum sulfates and to the stabilization of barium sulfates with no significant sulfur elimination (Figs. $4 \mathrm{a}$ and $4 \mathrm{~b}$, Table 3), in agreement with previous works [5]. Increasing the temperature to $800^{\circ} \mathrm{C}$ led to an increase of the hydrogen consumption attributed to the reduction of bulk barium sulfates (peak at $750^{\circ} \mathrm{C}$ ). The same behavior was observed for the $\mathrm{Pt} / 10 \mathrm{Ba} / \mathrm{CeZr}$ catalyst (Fig. 4c), but to a lower extent since after annealing at 
$800^{\circ} \mathrm{C}$ sulfate reduction was mainly completed near $700^{\circ} \mathrm{C}$ instead of $800^{\circ} \mathrm{C}$ on alumina containing materials. In order to check if bulk barium sulfates are formed during the ageing treatments at $600^{\circ} \mathrm{C}$ and $800^{\circ} \mathrm{C}$, the ageing of sulfated $\mathrm{Pt} / 10 \mathrm{Ba} / \mathrm{Al}$ and $\mathrm{Pt} / 10 \mathrm{Ba} / \mathrm{CeZr}$ catalysts was followed by in situ XRD. The spectra were recorded in situ after annealing the catalysts at $600^{\circ} \mathrm{C}$ and $800^{\circ} \mathrm{C}$ under air for $0.5 \mathrm{~h}$. On the sulfated catalysts, no peak corresponding to crystallized barium sulfates was observed at room temperature regardless of the catalyst (Fig. 5). This result does not exclude their formation, but the amount would be very small and the XRD peak is not detectable. As the TPR profile of the sulfated Pt/10Ba/Al catalyst shows (Fig. 1a), the hydrogen consumption near $750^{\circ} \mathrm{C}$ attributed to the reduction of bulk barium sulfates is indeed very small. The XRD spectra of the sulfated catalysts after ageing at $600^{\circ} \mathrm{C}$ show the appearance of broad peaks corresponding to crystallized $\mathrm{BaSO}_{4}$ (orthorhombic, barite-syn $2 \theta=$ $25.8^{\circ}, 26.8^{\circ}$ ) only for the $\mathrm{Pt} / 10 \mathrm{Ba} / \mathrm{Al}$ catalyst (Fig 5a). Finally, further evidence of crystallized $\mathrm{BaSO}_{4}$ was obtained for both catalysts after an annealing treatment at $800^{\circ} \mathrm{C}$. These results indicate that the formation of bulk barium sulfates is retarded on ceria-zirconia compared to alumina.

Otherwise, it can be concluded that ceria-zirconia promotes bulk barium sulfate reduction. Figure $4 \mathrm{c}$ shows that the reduction of these species is completed at $700^{\circ} \mathrm{C}$ on $\mathrm{Pt} / 10 \mathrm{Ba} / \mathrm{CeZr}$ instead of $800^{\circ} \mathrm{C}$ on alumina containing samples (Figs. $4 \mathrm{a}$ and $4 \mathrm{~b}$ ). A possible explanation may be given by considering the redox properties of ceria oxide. Indeed ceria can oxidize or reduce molecules depending on the composition of the inlet gas. Ceria $\left(\mathrm{Ce}^{4+}\right)$ can oxidize a molecule by losing an oxygen atom and a reduced surface $\left(\mathrm{Ce}^{3+}\right)$ can promote the reduction of a molecule by uptake of an oxygen atom. As the TPR profile of the sulfated $\mathrm{Pt} / 10 \mathrm{Ba} / \mathrm{CeZr}$ catalyst indicates (Fig. 4c), the reduction of ceria (peak at $250-400^{\circ} \mathrm{C}$ ) takes place before the reduction of sulfates (peak between $400-700^{\circ} \mathrm{C}$ ). It is then possible that reduced ceria leads to a destabilization of the S-O bonds from the sulfates. Another explanation may be the activation of hydrogen by ceria which will spill-over to the sulfate particles, thus promoting their reduction. For both hypothesis, proximity between ceria and barium is required. Conversely, on the alumina supported catalysts the reduction of large barium sulfates $(>10 \mathrm{~nm})$ would not be promoted by hydrogen spill-over [11]. 
(a)

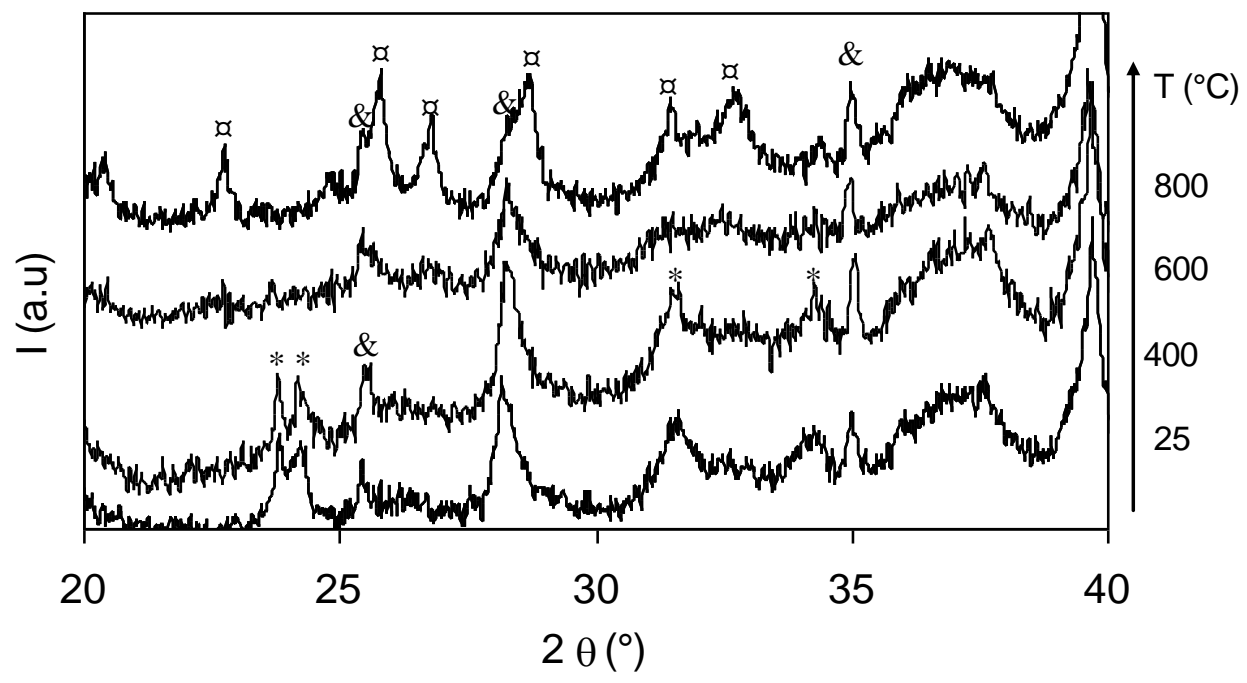

(b)

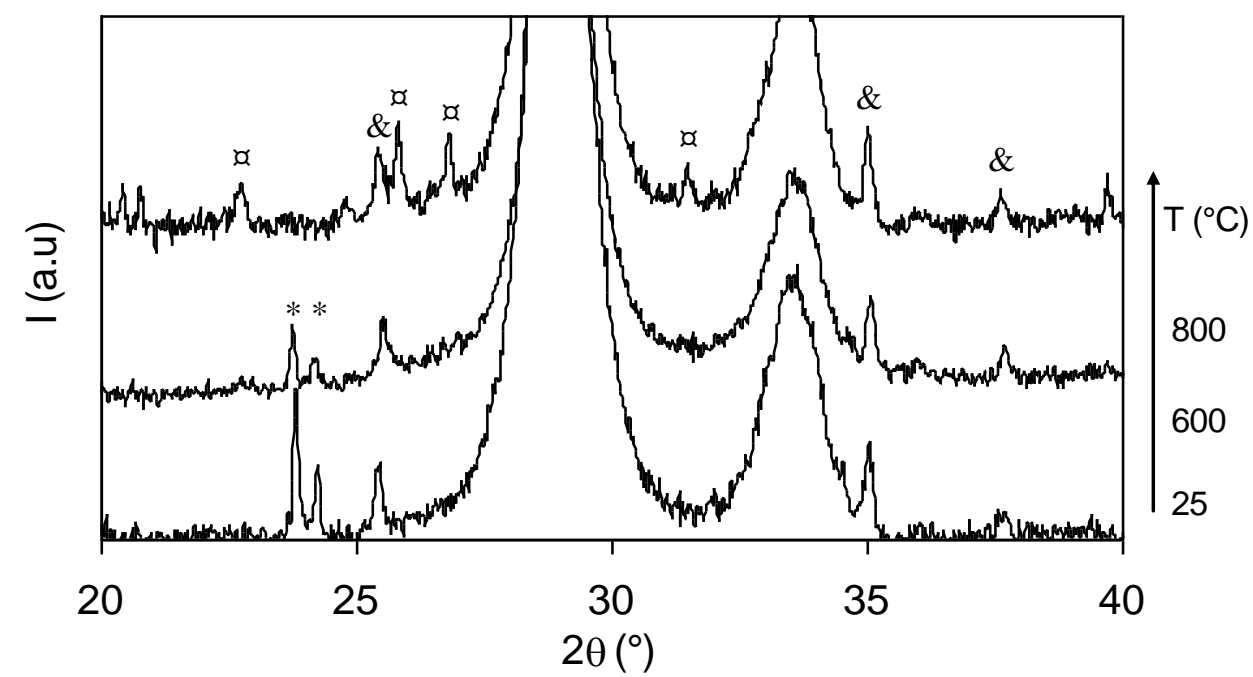

Figure 5 : XRD patterns at $25^{\circ} \mathrm{C}, 400^{\circ} \mathrm{C}, 600^{\circ} \mathrm{C}$ and $800^{\circ} \mathrm{C}$ of sulfated catalysts: (a) $\mathrm{Pt} / 10 \mathrm{Ba} / \mathrm{Al}$ and (b) $\mathrm{Pt} / 10 \mathrm{Ba} / \mathrm{CeZr}$. The catalysts were heated under air from $25^{\circ} \mathrm{C}$ up to $800^{\circ} \mathrm{C}$. (a) $\mathrm{BaSO}_{4}$, (*) $\mathrm{BaCO}_{3},(\&)$ support.

\section{$\underline{\text { Regeneration of sulfated and aged catalysts }}$}

The TPR profiles of the sulfated and annealed catalysts after regeneration at $550^{\circ} \mathrm{C}$, under a $\mathrm{H}_{2}$, $\mathrm{CO}_{2}$ and $\mathrm{H}_{2} \mathrm{O}$ containing mixture, are reported in Fig. 6. For comparison, the TPR profiles of sulfated catalysts are also reported. The corresponding hydrogen consumptions and the amounts of remaining sulfur are reported in Table 3. Generally, the amount of remaining sulfur increases with the temperature of the ageing treatment before regeneration. This result is in agreement with the formation of stable bulk barium sulfates which is promoted by the rise of the temperature under oxidizing conditions.

The regeneration at $550^{\circ} \mathrm{C}$ of sulfated catalysts aged at $600^{\circ} \mathrm{C}$ led to a more or less important sulfur elimination depending on catalyst composition: $\sim 15 \%$ for the $\mathrm{Pt} / 10 \mathrm{Ba} / \mathrm{Al}$ catalyst, 40 
$\%$ for the $\mathrm{Pt} / 20 \mathrm{Ba} / \mathrm{Al} 5.5 \mathrm{Si}$ and above $60 \%$ for the $\mathrm{Pt} / 10 \mathrm{Ba} / \mathrm{CeZr}$ catalyst. After ageing of the sulfated catalysts at $800^{\circ} \mathrm{C}$, the regeneration treatment is less effective for alumina containing samples with no significant sulfur elimination for the $\mathrm{Pt} / 10 \mathrm{Ba} / \mathrm{Al}$ catalyst and $\sim 10 \%$ for the $\mathrm{Pt} / 20 \mathrm{Ba} / \mathrm{Al} 5.5 \mathrm{Si}$. Conversely, more than $50 \%$ of sulfur were eliminated for the $\mathrm{Pt} / 10 \mathrm{Ba} / \mathrm{CeZr}$ sample (Table 4). This result confirms that the ceria-zirconia support plays an important role in barium sulfate elimination under rich conditions.

Table 4: NOx storage capacities measured at $300^{\circ} \mathrm{C}$ on $\mathrm{Pt} / 10 \mathrm{Ba} / \mathrm{Al}, \mathrm{Pt} / 20 \mathrm{Ba} / \mathrm{Al}$.5Si and $\mathrm{Pt} / 10 \mathrm{Ba} / \mathrm{CeZr}$ catalysts after different treatments.

\begin{tabular}{lcccccccc}
\hline Treatment & \multirow{2}{*}{ Fresh } & \multirow{2}{*}{ S } & \multirow{2}{*}{ S T600 } & \multirow{2}{*}{ S T800 } & \multirow{2}{*}{ S R500 } & \multirow{2}{*}{ S R550 } & $\begin{array}{c}\text { S T600 } \\
\text { R550 }\end{array}$ & $\begin{array}{c}\text { S T800 } \\
\text { R550 }\end{array}$ \\
\hline Pt/10Ba/Al & 13.8 & 4.6 & 7.8 & 11.1 & 11.9 & 15.6 & 15.3 & 12.0 \\
Pt/20Ba/Al5.5Si & 21.5 & 11.2 & 16.6 & 15.3 & 18.7 & 21.0 & 22.2 & 15.6 \\
Pt/10Ba/CeZr & 12.9 & 6.4 & 7.6 & 8.2 & 18.2 & 21.7 & 24.6 & 22.4 \\
\hline
\end{tabular}
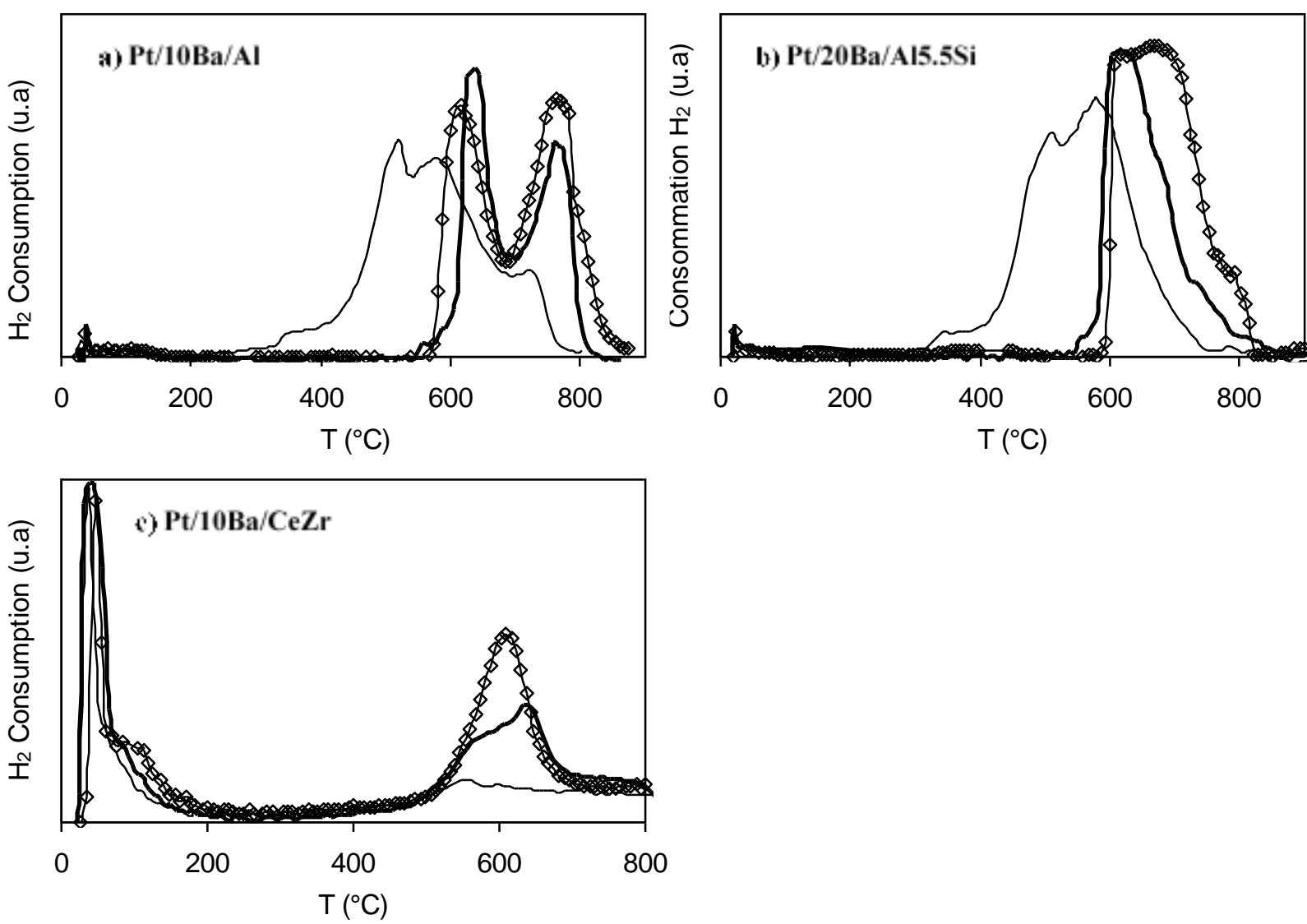

Figure 6: TPR profiles of a) $\mathrm{Pt} / 10 \mathrm{Ba} / \mathrm{Al}$, b) $\mathrm{Pt} / 20 \mathrm{Ba} / \mathrm{Al}$ 5.5Si and c) $\mathrm{Pt} / 10 \mathrm{Ba} / \mathrm{CeZr}$. (-) sulfated; (-) sulfated, aged at $600^{\circ} \mathrm{C}$ and then regenerated; (- - ) sulfated, aged at $800^{\circ} \mathrm{C}$ and then regenerated. The regeneration treatment was carried out at $550^{\circ} \mathrm{C}$ under $\mathrm{H}_{2}, \mathrm{CO}_{2}, \mathrm{H}_{2} \mathrm{O}$ and $\mathrm{N}_{2}$ containing mixture. 


\section{NOx storage capacity of regenerated catalysts}

In order to gain information about the efficiency of the regeneration treatment on the different sulfated catalysts, the NOx storage capacity was measured at $300^{\circ} \mathrm{C}$ under a mixture containing 350 ppm NO, $10 \% \mathrm{CO}_{2}, 10 \% \mathrm{H}_{2} \mathrm{O}$ and $10 \% \mathrm{O}_{2}$. The results are presented in Table 4. For comparison, the NOx storages of the fresh (non-sulfated) catalysts are also reported.

The regeneration at $550^{\circ} \mathrm{C}$ of sulfated catalysts, led to the total recovery of the initial NOx storage capacity whatever the catalyst, though some sulfur is still present on the materials, especially for the alumina containing ones. Moreover an increase in NOx storage capacity is observed after the regeneration treatment for the $\mathrm{Pt} / 10 \mathrm{Ba} / \mathrm{CeZr}$ catalyst $\left(21.7 \mu \mathrm{mol}_{\mathrm{g}} \mathrm{g}^{-1}\right.$ after regeneration versus $12.9 \mu \mathrm{mol} . \mathrm{g}^{-1}$ for the fresh catalyst). In order to investigate if this increase is linked both to the presence of sulfur and the reducing treatment, the fresh catalyst was treated under the same reducing mixture at $550^{\circ} \mathrm{C}\left(\mathrm{H}_{2}, \mathrm{CO}_{2}\right.$ and $\left.\mathrm{H}_{2} \mathrm{O}\right)$. The NOx storage capacity of the fresh catalyst after the reducing treatment increases from $12.9 \mu \mathrm{mol} . \mathrm{g}^{-1}$ to $22.8 \mu \mathrm{mol} . \mathrm{g}^{-1}$, indicating that the improvement in the NOx storage capacity is related only to the reducing treatment. The latter also induces an increase of catalyst oxidation activity (19\% versus $7 \%$ ) which can contribute to the enhancement of the NOx storage capacity at $300^{\circ} \mathrm{C}$. The same reducing treatment was performed on the $\mathrm{Pt} / 10 \mathrm{Ba} / \mathrm{Al}$ and $\mathrm{Pt} / 20 \mathrm{Ba} / \mathrm{Al}$.5Si catalysts. The $\mathrm{NOx}$ storage capacities of the fresh catalysts after the reducing treatment at $550^{\circ} \mathrm{C}$ were 15.4 and $22.3 \mu \mathrm{mol} . \mathrm{g}^{-1}$, for the $\mathrm{Pt} / 10 \mathrm{Ba} / \mathrm{Al}$ and $\mathrm{Pt} / 20 \mathrm{Ba} / \mathrm{Al}$.5Si, respectively $\left(13.8\right.$ and $21.5 \mu \mathrm{mol} . \mathrm{g}^{-1}$ with non-reduced samples). These results show that the promoting effect of the treatment under rich conditions is linked to the presence of the ceria-zirconia oxide [32]. It may result from a migration of cerium from the bulk to the surface during the reducing treatment, as suggested by Fan et al. [28]. The formation of a cerium rich surface could promote the oxidation of NO to $\mathrm{NO}_{2}$ and the spill over of $\mathrm{NO}_{2}$ to storage sites.

The decrease of the regeneration temperature of sulfated catalysts to $500^{\circ} \mathrm{C}$ led to lower performances whatever the catalyst (Table 4). For the Pt/10Ba/Al, only $85 \%$ of the initial NOx storage properties are recovered, although nearly the same amount of sulfur is eliminated at $500^{\circ} \mathrm{C}$ and $550^{\circ} \mathrm{C}$. This result can be explained by the higher migration of sulfates, previously observed for the regeneration treatment at $550^{\circ} \mathrm{C}$ (Fig. 3), leading to the recovery of more active Ba surface sites. Likewise, the $\mathrm{Pt} / 20 \mathrm{Ba} / \mathrm{Al} 5.5 \mathrm{Si}$ catalyst recovered $85 \%$ of its initial NOx storage capacity after regeneration at $500^{\circ} \mathrm{C}$. As for the $\mathrm{Pt} / 10 \mathrm{Ba} / \mathrm{CeZr}$ catalyst, it shows a lower NOx storage capacity after regeneration at $500^{\circ} \mathrm{C}\left(18.2 \mu \mathrm{mol} . \mathrm{g}^{-1}\right.$ versus $21.7 \mu \mathrm{mol} . \mathrm{g}^{-1}$ at $\left.550^{\circ} \mathrm{C}\right)$, probably linked to the less effective sulfur elimination previously observed (Table 3 ). 
The annealing treatment at $600^{\circ} \mathrm{C}$ of sulfated catalysts did not modify the efficiency of the regeneration at $550^{\circ} \mathrm{C}$. Indeed, sulfated catalysts annealed at $600^{\circ} \mathrm{C}$ and sulfated catalysts show the same performances after regeneration at $550^{\circ} \mathrm{C}$ (Table 4). On the other hand, the regeneration treatment leads to lower NOx storage trapping properties on sulfated $\mathrm{Pt} / 10 \mathrm{Ba} / \mathrm{Al}$ and $\mathrm{Pt} / 20 \mathrm{Ba} / \mathrm{Al} 5.5 \mathrm{Si}$ catalysts annealed at $800^{\circ} \mathrm{C}$, while the $\mathrm{Pt} / 10 \mathrm{Ba} / \mathrm{CeZr}$ catalyst presents similar NOx storage capacities, whatever the ageing temperature. The different behaviors observed on alumina containing catalysts compared to the ceria-zirconia one can be explained by a higher sintering of the Ba component on the formers. Indeed, the TPR of sulfated catalysts previously reported in Figure 4, have shown that the amount of bulk barium sulfates was strongly enhanced after ageing at $800^{\circ} \mathrm{C}$. In order to check this hypothesis, the fresh $\mathrm{Pt} / 10 \mathrm{Ba} / \mathrm{Al}$ and $\mathrm{Pt} / 20 \mathrm{Ba} / \mathrm{Al} 5.5 \mathrm{Si}$ catalysts were annealed at $800^{\circ} \mathrm{C}$ and then treated in rich conditions at $550^{\circ} \mathrm{C}$ before NOx storage measurements at $300^{\circ} \mathrm{C}$. The values obtained were close to that reported in Table 4 for the sulfated samples annealed at $800^{\circ} \mathrm{C}$ and regenerated at $550^{\circ} \mathrm{C}(\mathrm{S}$ T800 R550): $12.3 \mu \mathrm{mol} . \mathrm{g}^{-1}$ versus $12.0 \mu \mathrm{mol} . \mathrm{g}^{-1}$ for $\mathrm{Pt} / 10 \mathrm{Ba} / \mathrm{Al}$ and $15.4 \mu \mathrm{mol} . \mathrm{g}^{-1}$ versus 15.6 $\mu$ mol.g $\mathrm{g}^{-1}$ for $\mathrm{Pt} / 20 \mathrm{Ba} / \mathrm{Al} 5.5 \mathrm{Si}$.

\section{Conclusion}

The influence of the support oxide $\left(\mathrm{Al}_{2} \mathrm{O}_{3}, \mathrm{Al}_{2} \mathrm{O}_{3}-5.5 \mathrm{wt} \% \mathrm{SiO}_{2}\right.$ and $\left.\mathrm{Ce}_{0.7} \mathrm{Zr}_{0.3} \mathrm{O}_{2}\right)$ as well as the Ba loading was studied with regard to sulfur resistance and regeneration. Barium sulfate stability was influenced by the support oxide and the Ba loading. For alumina containing catalysts the amount of deposited sulfur and sulfate stability under hydrogen increase with the Ba loading. Conversely, no modification in barium sulfates stability was observed for $\mathrm{Ce}-\mathrm{Zr}$ supported samples, whatever the Ba loading. Furthermore, for the latter support, a decrease of the amount of deposited sulfur with the increase of Ba loading was noticed. This result was explained by both a decrease of the BET surface area and the limitation of SOx diffusion due to higher barium crystallite size.

Ageing at $600^{\circ} \mathrm{C}$ under oxidizing conditions of the sulfated $\mathrm{Pt} / 10 \mathrm{Ba} / \mathrm{Al}$ catalyst led to the formation of crystallized $\mathrm{BaSO}_{4}$ detected by XRD. Their presence was observed only after ageing at $800^{\circ} \mathrm{C}$ under the same conditions for $\mathrm{Pt} / 10 \mathrm{Ba} / \mathrm{CeZr}$. Moreover, ceria-zirconia led to a decrease of bulk $\mathrm{BaSO}_{4}$ stability under hydrogen, their reduction temperature being about $100^{\circ} \mathrm{C}$ lower than on alumina containing materials. The sulfates elimination under rich conditions $\left(\mathrm{H}_{2}, \mathrm{CO}_{2}, \mathrm{H}_{2} \mathrm{O}, \mathrm{N}_{2}\right)$ was more efficient on ceria-zirconia supported sample: 85-90\% of sulfur are eliminated at $550^{\circ} \mathrm{C}$ on $\mathrm{Pt} / 10 \mathrm{Ba} / \mathrm{CeZr}$ while only $55 \%$ and $40 \%$ are eliminated on $\mathrm{Pt} / 10 \mathrm{Ba} / \mathrm{Al}$ and $\mathrm{Pt} / 20 \mathrm{Ba} / \mathrm{Al} 5.5 \mathrm{Si}$, respectively. The same trend was observed on sulfated 
catalysts annealed at high temperature $\left(600^{\circ} \mathrm{C}\right.$ and $\left.800^{\circ} \mathrm{C}\right)$ before regeneration, but to a less extent.

Sulfation of the catalysts induced a loss of the NOx storage capacity (measured in the presence of $10 \% \mathrm{CO}_{2}$ and $10 \% \mathrm{H}_{2} \mathrm{O}$ ) that ranges between $50 \%$ and $70 \%$, depending on catalyst composition. All the catalysts recovered their initial NOx storage capacity after regeneration at $550^{\circ} \mathrm{C}$, even with an improvement in the case of $\mathrm{CeZr}$ containing material. This behavior is linked mainly to the reduction of ceria during the rich treatment. Eventually, the ageing at $800^{\circ} \mathrm{C}$ of sulfated catalysts before regeneration did not lower significantly the performance of the $\mathrm{Pt} / 10 \mathrm{Ba} / \mathrm{CeZr}$ catalyst, contrary to the alumina containing samples.

In conclusion, concerning sulfur deactivation of NOx storage catalysts, the results reported in the present work show the interest to include ceria-zirconia in the composition of NSR catalysts.

\section{Acknowledgments}

This work was financially supported by the French Environment and Energy Management Agency (ADEME) and the Poitou-Charentes Region.

\section{References}

[1] N. Miyoshi, S. Matsumoto, K. Katoh, J. Harada, N. Takahashi, K. Yokota, M. Sugiura, K. Kasahara, SAE Tech. Paper 950809, 1995.

[2] W. S. Epling, L. E. Campbell, A. Yezeerets, N. W. Currier, J. E. Parks II, Catal. Rev. 46 (2004) 163.

[3] H. Mahzoul, L. Limousy, J. Brilhac, P. Gilot, J. Anal. Appl. Pyrolysis 56 (2000) 179.

[4] S. Matsumoto, Y. Ikeda, H. Suzuki, M. Ogai, N. Myoshi, Appl. Catal. B 25 (2000) 115.

[5] S. Elbouazzaoui, E.C. Corbos, X. Courtois, P. Marecot, D. Duprez, Appl. Catal. B 61 (2005) 236.

[6] H. Abdulhamid, E. Fridell, J. Dawody, M. Skoglundh, J. Catal. 241 (2006) 200.

[7] C. Sedlmair, K. Seshan, A. Jentys, J. Lercher, Catal. Today 75 (2002) 413.

[8] F. Rohr, U. Gobel, P. Kattwinkel,ller, S. Philipp, P. Gélin, Appl. Catal. B 70 (2007) 189.

[9] C. Courson, A. Khalfi, H. Mahzoul, S. Hodjati, N. Moral, A. Kiennemann, P. Gilot, Catal. Comm. 3 (2002) 471.

[10] S. Poulston, R.R. Rajaram, Catal. Today 81 (2003) 603.

[11] X. Wei, X. Liu, M. Deeba, Appl. Catal. B: 58 (2005) 41.

[12] Z. Liu, J. Anderson, J. Catal. 228 (2004) 243.

[13] H. Mahzoul, P. Gilot, J.F. Brilhac, B.R. Stanmore, Top. Catal 16/17 (2001) 293.

[14] J. Dawody, M. Skoglundh, L. Olsson, E. Fridel, Appl. Catal. B 70 (2007) 179.

[15] Ch. Sedlmair, K. Seshan, A. Jentys, J.A. Lercher, Catal. Today 75 (2002) 413.

[16] A. Amberntsson, M. Skoglundh, S. Ljungstrom, E. Fridell, J. Catal 217 (2003) 253.

[17] K. Yamazaki, T. Suzuki, N. Takahasi, K. Yojota, M. Sugiura, Appl. Catal. B 30 (2001) 459.

[18] F. Basile, G. Fornasari, A. Grimandi, M. Livi, A. Vaccari, Appl. Catal. B 69 (2006) 58.

[19] J. Xiao, X. Li, S. Deng, F. Wang, L. Wang, Catal. Comm 8 (2007) 926. 
[20] S. Hodjati, C. Petit, V. Pitchon and A. Kiennemann, Appl. Catal. B 30 (2001) 247.

[21] H.Y. Huang, R.Q. Long, R.T. Yang, Appl. Catal. B 33 (2001) 127.

[22] N. Takahashi, A. Suda, I. Hachisuka, M. Sugiura, H. Sobukawa, H. Shinjoh, Apll. Catal. B, 72 (2007) 187.

[23] K. Yamamoto, R. Kikuchi, T. Takeguchi, K. Eguchi, J. Catal 238 (2006) 449.

[24] G. Centi, G. Fornasari, C. Gobbi, M. Livi, F. Trifirò and A. Vaccari, Catal. Today 73 (2002) 287.

[25] J. M. Clacens, R. Montiel, H. Kochkar, F. Figueras, M. Guyon, J. C. Beziat, Appl. Catal. B 53 (2004) 21.

[26] E.C. Corbos, X. Courtois, N. Bion, P. Marecot, D. Duprez, Apll. Catal. B (2007) Accepted for publication.

[27] J. Dawody, M. Skoglundh, L. Olsson, E. Fridell, J. Catal. 234 (2005) 206.

[28] J. Fan, X. Wu, R. Ran, D. Weng Appl. Surf. Sci., 245 (2005) 162.

[29] M.F. Luo, X.M. Zheng, Appl. Catal. A, 189 (1999) 15.

[30] M. Waqif, P. Bazin, O. Saur, J.C. Lavalley, G. Blanchard, O. Touret, Appl. Catal. B 11 (1997) 193.

[31] P. Engström, A. Amberntsson, M. Skoglundh, E. Fridell and G. Smedler, Appl. Catal. B 22 (1999) L241.

[32] F. Fally, V. Perrichon, H. Vidal, J. Kaspar, G. Blanco, J. M. Pintado, S. Bernal, G. Colon, M. Daturi and J. C. Lavalley, Catal. Today 59 (2000) 373. 